\title{
Economic Comparison of Agricultural Sector of Eurasian Countries - Is There Any Potential for Development Through Economic Cooperation?
}

\author{
I. Benešová, Z. Novotná, P. Šánová, A. Laputková \\ Faculty of Economics and Management, Czech University of Life Sciences Prague, Czech Republic
}

\begin{abstract}
Eurasia represents an important economic region for the majority of the post-Soviet republics. The structure of their economies is highly dissimilar and reflects the status of agriculture. The aim of the paper is to analyse the relation between agriculture index and GDP per capita Using the basic economic indicators in agriculture (contribution of agriculture to GDP, share of employment in agriculture, agriculture value added per worker and share of rural population) as well as the cluster analysis, the countries were divided into four groups. There are sub-groups within the post-Soviet republics, differing considerably in the status of agriculture in their national economy. A negative correlation between GDP per capita (PPP) and the level of the agriculture index has been proved in the monitored countries.
\end{abstract}

\section{Keywords}

Eurasia, post-Soviet countries, agriculture index, economic indicators, cluster analysis, economic development.

Benešová, I., Novotná, Z., Šánová, P. and Laputková, A. (2016) "Economic Comparison of Agricultural Sector of Eurasian Countries - Is There Any Potential for Development Through Economic Cooperation?", AGRIS on-line Papers in Economics and Informatics, Vol. 8, No. 2, pp. 19-31. ISSN 1804-1930. DOI: 10.7160/aol.2016.080202.

\section{Introduction}

Agriculture represents one of the essential parts of any national economy. In the past decades, agriculture of the majority of the world countries have undergone a fundamental transformation connected with the growth of innovations and the use of new technologies. These have led to the increase of productivity as well as effectiveness in the agricultural sector as a whole. As early as in 1961, (Mellor, 1961) it was proved that agriculture has a positive impact on economic growth regardless of its technological maturity.

After the Second World War, there were theories which explaining the prospects of economic development. (Rosentein-Rodan, 1943) discovers two possible solutions for post-war industrialization - the Russian model based on the planned economy and autarchy or integration into the international economy while using free workforce.

The post-war literature focusing on economic growth is characterized by four classic approaches to development. These can also be understood as development stages related to the area. Each of these theories contains at least basic concepts (concerning for example competitive advantage, international labour distribution, decreasing revenues and their relation to human capital or other resources, the relation between income per capita and population growth, technological progress and economic growth), for instance, works of A. Smith, D. Ricard, T. Malthus and later of J. Schumpeter.

Regarding agriculture, dual economy theories are most frequently applied in which, using a set of measures, an under-developed economy highly dependent on a traditional agricultural sector is gradually transformed into more modern and more industrial production. This theory was originally based on the works of Higgins (1956) and Myint (1971), as well as Lewis (1955; 1979; 1954) and Chenery and Bruno (1962) later Barro and Sala-i-Martin (2003), Carter (2004), Robertson and Landon-Lane (2001) or Robertson (1999) might also be mentioned.

The term Eurasia is used from a geographic perspective, with no geological border between Europe and Asia. Based on similar historical development, Europe and Asia have been connected to form a single unit. In this regard, 
Mostafa (2013) points out that no definition states what the term "Eurasia" contains. Vinokurov and Libman (2012) understand the issues connected with "Eurasia" in three different areas: post-Soviet Eurasia, Eurasianism and Eurasia as a continent. In this research, the term Eurasia is used in connection with the region of the post-Soviet countries. The integration process between individual countries with a different level of the economy can gradually contribute to reduction of disparities between individual member states. The key to successful regional cooperation is in using comparative advantages of all the participating countries (Fathipour and Ghahremanlou, 2014), which will enable them to be presented at a global level as a part of the whole and this way defend their mutual interests. In addition to this, functional regional cooperation encourages the influx of capital and enhances productivity (Kumar, 2015). It might be stated that unless regional cooperation is functional, the paradigm of globalization cannot function (Dutta, 2002). Eurasian countries usually face the same problems which need to be solved together, through closer cooperation. These concern political, economic and security problems, while cooperation is the logical outcome of interconnectedness of the countries' economies and of their interdependency (Obydenkova, 2011).

Over the last two decades, agriculture of the post-Soviet republics has undergone significant changes (Svatoš, Smutka, and Ishchukova, 2014); however, it remains one of the most protected parts of the national economy in the majority of the world countries (Garmann, 2014; R. Barro, 2004; Hansen, 2016; Wegren, 2016; Anderson et al., 2014). Therefore, the question arises as to whether agriculture can be the driver of economic cooperation that will lead to economic growth. This is derived from the fact that, provided that the economic structure of agriculture in these countries is similar, they are likely to converge. Nevertheless, this similarity might be apparent between some countries only and the so called sub-clubs (King, 2016b; King, 2016a) or the hub-and-spoke principle might be created (Chong and Hur, 2008; Hur et al., 2010; Kirkow, 1999). The aim of the paper is to analyse the similarities of the agricultural between postSoviet countries and to find the relation between agriculture index and GDP per capita for these countries.

\section{Materials and methods}

The countries in the Eurasian region are highly heterogeneous. The countries in question are as follows: Armenia (ARM), Azerbaijan (AZE), Belarus (BLR), Georgia (GEO), Kazakhstan (KAZ), Kyrgyzstan (KGZ), the Republic of Moldova (MDA), the Russian Federation (RUS), Tajikistan (TJK), Turkmenistan (TKM), Ukraine (UKR) and Uzbekistan (UZB). The three Baltic States (Estonia, Latvia and Lithuania) have not been considered, as these are now members of the European Union.

Regarding the post-Soviet countries and their possible cooperation, one fundamental problem has been identified, namely insufficient data available in order to analyze individual crossborder agricultural activities. For this reason, there are no studies discussing this important sector of the national economy. Libman and Vinokurov (Libman and Vinokurov, 2012) are an exception in this regard, since they incorporate one agricultural indicator (contribution of grain trade to the total GDP) into their overall evaluation of cooperation between the post-Soviet republics.

The data have been obtained from the FAOSTAT database, International Labour Organization (ILO), Interstate Statistical Committee of the CIS, Eurasian development bank and from national statistical institutes of the monitored countries.

Not all the data are available for all of the countries. Whenever the data are unavailable, this fact will be mentioned in the paper. The analysis has been conducted for years $2000-2012$. We are aware of the fact that the time period may be inadequate, especially its end. Unfortunately, the latest data in the field of agriculture which can be compared for the majority of the countries have been unavailable after 2012. Whenever these are available, the newest data will be used. Whenever necessary, the data entering the analysis were extrapolated to the population, which enabled to reduce the influence of substantial differences given by different sizes of the states.

The paper can be divided into two main parts. At first, descriptive and comparative statistics and data visualization are used for comparison.

The second part of the paper include cluster analysis and the creation of the agricultural index. This stage can be divided into four consequential steps:

1) The original dataset consisted of 50 variables. All the original variables are mentioned 
in appendix 1. Due to significant interregional differences between the monitored countries as well as the fact that the data contained a large number of outliers, identification of these was required. Subsequently, these data were eliminated from further research and standardization of variables was carried out in order to avoid misrepresentation of the results due to differences in unit sequences.

The input data were standardized using the norming Z-function. Each attribute was normalized into its $Z$-score by deducting the average and by dividing the standard deviation.

$z=\frac{x-\mu}{\sigma}$

Using this transformation, scale differences and attributes often differing in the order of magnitude were eliminated (Meloun and Militky, 2004). The original data set was reduced using correlation analysis

$s_{x y}=\frac{\sum_{i=1}^{n}\left(x_{i}-\bar{x}\right)\left(y_{i}-\bar{y}\right)}{n-1}$

and variation coefficients

$c v=\frac{\sigma}{\mu}$

to exclude redundancies between variables and their interconnectivity.

2) The cluster analysis was applied to the standardized data. The purpose of clustering the data, also known as cluster analysis, is to discover natural grouping(s) of a set of patterns, points, or objects (Jain, 2010). Initially, hierarchical cluster analysis was applied in order to determine the most suitable number of clusters. Ward's method was used, also referredto as the incremental sum of squares method thatisbased onwithintheclusterdistances and the between the cluster distances (Ward, 1963), the aim of which is to minimize cluster heterogeneity. The intra-cluster variance (VSS) is given by the correlation:

$V S S=\sum_{j=1}^{m} \sum_{i=1}^{k}\left(x_{i j}-\overline{x_{j}}\right)^{2}$

$\overline{x_{j}}=\frac{1}{k} \sum_{i=1}^{k} x_{i j}$
3) Subsequently, the non-hierarchical clustering method based on Euclidean distance was used using K-means clustering.

In order to determine the number of clusters, the elbow rule method was used (Kodinariya and Makwana, 2013).

$$
d_{E}\left(x_{k}, x_{1}\right)=\sqrt{\sum_{j=1}^{m}\left(x_{k j}-x_{i j}\right)^{2}}
$$

$\mathrm{K}$-means clustering is a frequently used method in order to automatically partition a dataset into k-groups. It proceeds by selecting k-initial cluster centres and then iteratively refining them as follows:

- Each instance is assigned to its closest cluster centre.

- Each cluster centre is updated to be the mean of its constituent instances (Wagstaff et al., 2001).

4) Afterward, a composite agriculture index for each country was constructed and compared with GDP per capita (PPP). The variables entering the composite indicator were selected based on the cluster analysed. All the variables would be given equal weight (OECD, 2008; Saisana and Saltelli, 2011; Sharpe and Andrews, 2012).

In order to verify the correlation between the composite agriculture indicator and GDP, correlation coefficient will be used and the final value will be tested.

\section{Results and discussion}

The status of agriculture in the economies of the post-Soviet republics

The dissolution of the Soviet Union led to significant socio-economic changes which had a profound impact on agricultural economics of these countries including a considerable decline in the contribution of agriculture to GDP or overall employment. Table 1 provides basic characteristics of agriculture in the post-Soviet republics. Regarding agriculture of the post-Soviet republics, their most distinct feature is considerable heterogeneity and asymmetry between individual states. There are significant differences between the monitored countries related to the economic potential of agriculture, which is connected with basic production factors. There are considerable differences between the share of workers in agriculture, contribution of agriculture to GDP or labour productivity in agriculture. 


\begin{tabular}{|c|c|c|c|c|c|}
\hline Country & $\begin{array}{l}\text { Agricultural land } \\
\qquad(\mathrm{km} 2)\end{array}$ & $\begin{array}{c}\text { Share of } \\
\text { agricultural land on } \\
\text { total area }(\%)\end{array}$ & $\begin{array}{c}\text { Share of workers } \\
\text { in agriculture } \\
(\%)\end{array}$ & $\begin{array}{l}\text { Arable land } \\
\text { (ha) }\end{array}$ & $\begin{array}{c}\text { Proportion of arable } \\
\text { land on total area } \\
(\%)\end{array}$ \\
\hline AZE & 47683.00 & 57.68 & 37.70 & 1896800 & 22.94 \\
\hline ARM & 16830.00 & 59.11 & 38.90 & 448400 & 15.74 \\
\hline BLR & 87960.00 & 43.34 & 10.50 & 5522000 & 27.21 \\
\hline GEO & 24650.00 & 35.47 & 53.40 & 400000 & 5.75 \\
\hline KAZ & 2079750.00 & 77.07 & 31.00 & 22900000 & 8.48 \\
\hline KGZ & 105913.00 & 55.22 & 34.00 & 1276600 & 6.65 \\
\hline MDA & 24600.00 & 74.86 & 26.39 & 1814000 & 55.20 \\
\hline RUS & 2143500.00 & 13.08 & 9.69 & 119750000 & 7.31 \\
\hline TJK & 48750.00 & 34.83 & 66.50 & 860000 & 6.14 \\
\hline TKM & 338380.00 & 72.00 & 48.40 & 1940000 & 4.10 \\
\hline UZB & 266900.00 & 62.74 & 63.90 & 4350000 & 10.22 \\
\hline UKR & 412970.00 & 71.28 & 17.20 & 32518000 & 56.13 \\
\hline
\end{tabular}

Source: own processing based on statistical data from WB, ILO, CIS and Eurasian Development Bank

Table 1: Basic agricultural indicators of post-Soviet countries (2013).

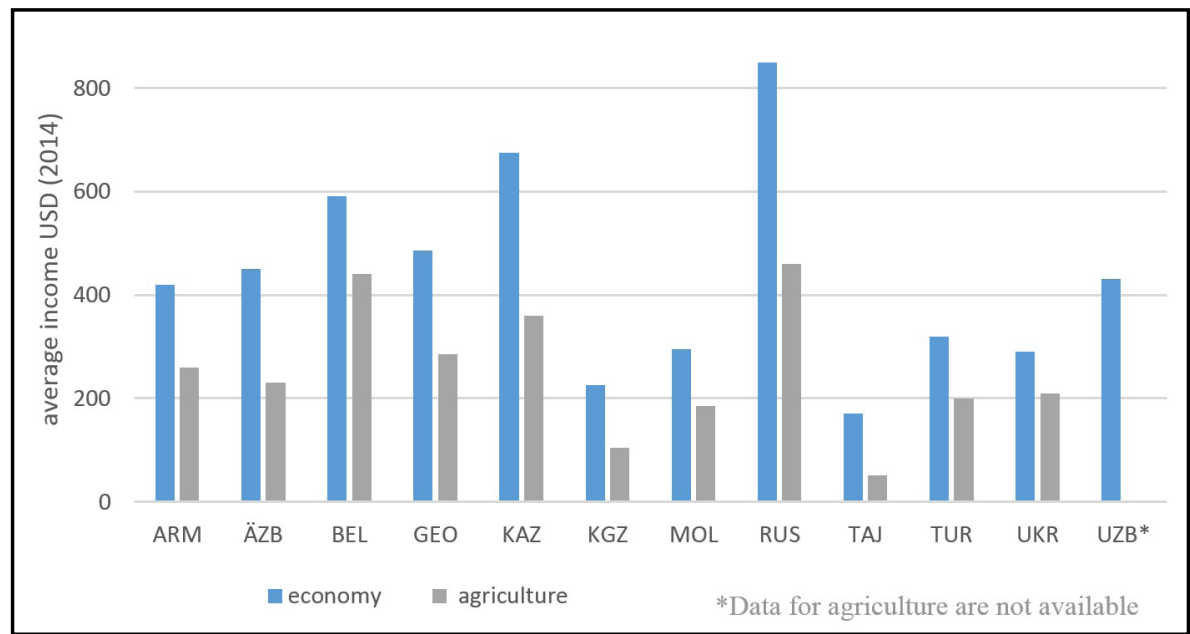

Source: own processing based on the data from CIS and national statistical institutes

Figure 1: Income of workers in agriculture.

The total population of the post-Soviet republics approaches 287 million. More than one third of the population lives in rural areas. However, this proportion fluctuates when comparing the countries as well as within individual states. Tajikistan reaches the highest levels with more than $70 \%$ of its population living in rural areas; on the contrary, in Belarus and Ukraine, the number slightly exceeds $20 \%$.

$20 \%$ of the population in the monitored countries work in agriculture, which amounts to almost 19 million people. Again, there are significant differences. Georgia reaches the highest levels, the Russian Federation and Belarus the lowest. Contribution of agriculture to GDP reaches $12.5 \%$.
In 2014, this amounted to almost 63 billion USD.

In 2014, the income of workers in agriculture reached half of the average monthly income in the monitored countries (graph 1). The Russian Federation and Belarus traditionally reach the highest average levels of income. Conversely, Tajikistan long-term reaches the lowest income levels, amounting to approximately 50 USD in 2014. The majority of the monitored countries also show trade deficit in agricultural and food products.

In the monitored period, a significant change has been detected in how important each sector of the national economy is in terms of its contribution 
to overall economic performance. The majority of the post-Soviet countries follow the trend evident in the developed countries where the importance of the role of agriculture in national economy has been undermined. In the monitored period, the contribution of agriculture to GDP has decreased by 7 p.p., whereas in 2000 the contribution of the primary sector to GDP was almost $22 \%$, in 2013 mere $13 \%$.

However, when comparing contribution of added value of each sector of the national economy to GDP, a significant difference between the monitored countries is evident. The highest contribution of agriculture can be seen in Tajikistan, where agriculture comprised $27.4 \%$ of its GDP in 2013. Armenia follows with $21.9 \%$ and Uzbekistan with $19.1 \%$. More than $10 \%$ of agriculture value added in GDP is also recorded in Kyrgyzstan, Moldova, Turkmenistan and Ukraine, with Russia (3.99\%), Kazakhstan (4.92\%) and Azerbaijan (5.66\%) occupying the opposite end.

In 2000, Kyrgyzstan reached the highest share of agriculture value added in GDP - more than $35 \%$. Uzbekistan also demonstrated high levels (34.5\%). All the countries showed a declining tendency in the monitored period. However, this tendency was discontinued in 2009 when the importance of agriculture started growing again in five of the monitored countries (Tajikistan, Moldova, Armenia, Turkmenistan and Ukraine). Owing to this, there has also been a slight increase in the median level in the monitored countries. Since 2009, the remaining countries have been experiencing stagnating contribution. The most stable contribution can be seen in Russia; however, this reflects its low basis (6\%) in 2000.
Russia reaches the highest levels of agricultural production in absolute values, followed by Ukraine and Uzbekistan. Regarding the Russian Federation, the total value of agricultural production is almost double in comparison with that of Ukraine and quadruple in comparison with that of Uzbekistan. On the other hand, Armenia and mainly Georgia are countries with the lowest value of agricultural production.

However, when taking into account agricultural yield per area, the order will change. Belarus shows the highest values of agricultural production per area, followed by Armenia and Ukraine. Kazakhstan and Turkmenistan reach the lowest values. Regarding the number of workers, Belarus is the most efficient, followed by Russia and Uzbekistan. Azerbaijan and Tajikistan reach the lowest values.

When taking into account the plant production only, the order of the countries with the highest value of production in absolute figures is the same. In terms of the area unit, Moldova and Ukraine reach the highest level of effectiveness. On the contrary, Kyrgyzstan, Turkmenistan and Kazakhstan reach very low levels of yield per area unit. This is the result of the way these countries are managed, with extensive agriculture mainly. When taking into account the worker in agriculture, Belarus, Russia and Ukraine show the highest levels of productivity. Again, this reflects the management style as well as their focus on different types of commodities. Animal production represents an important part of the agrarian sector in the monitored countries. Belarus, Russia and Turkmenistan reach the highest levels of productivity. Conversely, the lowest levels of productivity are evident in Tajikistan.

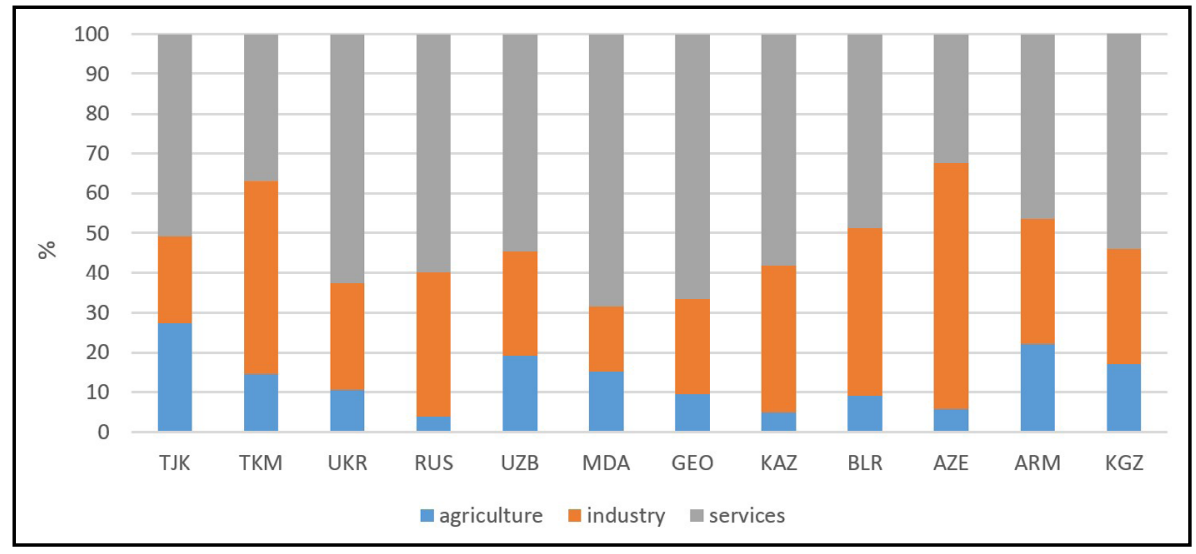

Source: own processing based on WB

Figure 2: Contribution of individual sectors of national economy to GDP. 
Similarities between economic indicators of Eurasian countries in agricultural production

Using the basic indicators characterizing the economic situation in agriculture (that is the average contribution of agriculture to GDP and the share of workers in agriculture in the total number of employees), the countries can be divided into four groups, plus Tajikistan. The first group contains Russia, Belarus and Ukraine. The share of workers in agriculture as well as the contribution of agriculture to GDP in these countries is low. The highest added value per worker in agriculture is created in Belarus. The second group of the countries consists of Kazakhstan and Azerbaijan. Both countries show low contribution of agriculture to GDP; at the same time, this sector is relatively important in terms of employment. This is also strongly influenced by the proportion of agricultural population which is relatively high, reaching $40-60 \%$. Another group of countries where agriculture represents an important source of employment is comprised of Turkmenistan and Georgia. Armenia, Moldova, Kyrgyzstan and Uzbekistan represent a heterogeneous group of countries. These countries reach higher contribution of agriculture to GDP, and at the same time a high share of employment in GDP. The lowest share of rural population in this case can be seen in Armenia, which also shows the highest added value per worker. At the same time, however, agriculture represents an important source of employment for almost $40 \%$ of workers. Regarding the post-Soviet republics, Tajikistan is an extreme example by reaching almost a $70 \%$ share of employment and at the same time more than $25 \%$ contribution to GDP.
When applying the cluster analysis to the above variables (contribution of agriculture to GDP, the share of employment in agriculture, agriculture value added per worker and the share of rural population), while assuming 4 clusters, we will obtain the following groups of countries.

\begin{tabular}{|l|l|l|}
\hline Cluster & Country & Characteristics \\
\hline 1 & Armenia, Turkmenistan, & $\begin{array}{l}\text { High employment and } \\
\text { higher productivity }\end{array}$ \\
\hline 2 & $\begin{array}{l}\text { Azerbaijan, Georgia, } \\
\text { Kazakhstan, Moldova, } \\
\text { Ukraine, }\end{array}$ & $\begin{array}{l}\text { High employment } \\
\text { in agriculture and low } \\
\text { productivity }\end{array}$ \\
\hline 3 & Belarus, Russia, & $\begin{array}{l}\text { High productivity } \\
\text { countries }\end{array}$ \\
\hline 4 & $\begin{array}{l}\text { Kyrgyzstan, Tajikistan, } \\
\text { Uzbekistan. }\end{array}$ & Rural countries \\
\hline
\end{tabular}

Source: own processing based on statistical data from WB, ILO, CIS and Eurasian Development Bank

Table 2: division of the countries into individual groups.

The first and the second cluster show the closest similarities, whereas the third and the fourth almost none. Agricultural production per worker is the most important variable in clustering, the share of rural population and contribution of agriculture to GDP follow. The share of workers in agriculture in the total number of employees is least significant.

Armenia and Turkmenistan show considerable contribution of agriculture to GDP and reach lower labour productivity levels. The contribution of agriculture to GDP in the second group of countries reaches maximum 15\%. Regarding this indicator, they are closest to Russia and Belarus, which comprise the third group of countries. These reach the highest levels of labour productivity and lowest contribution of agriculture to GDP,

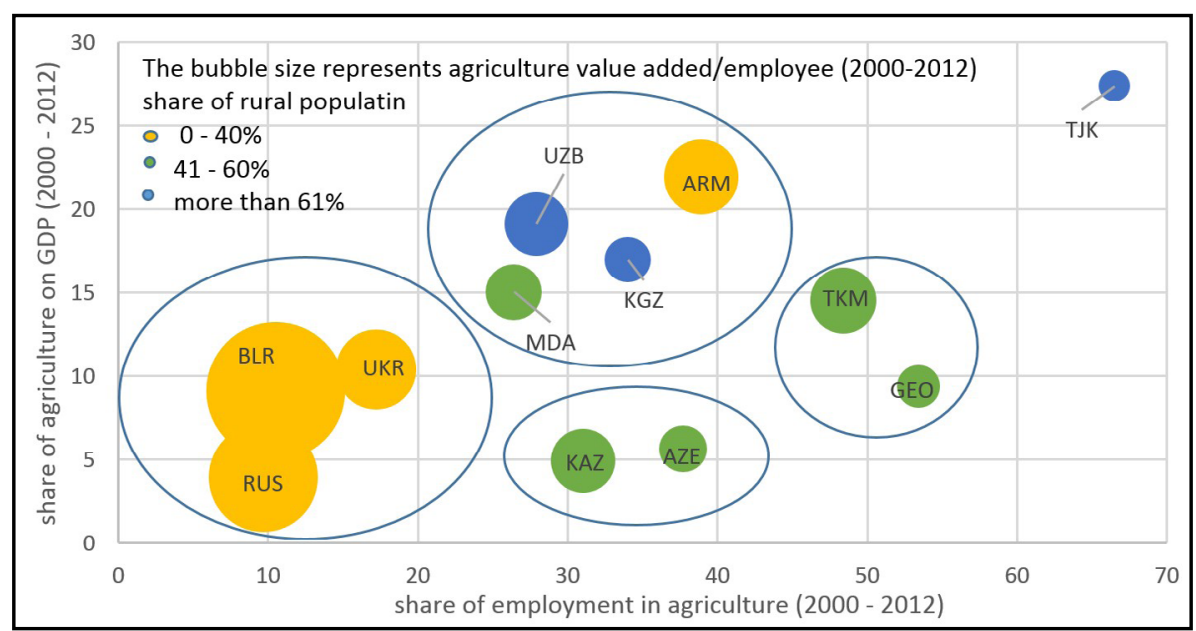

Source: own processing based on statistical data from WB, ILO, CIS and Eurasian Development Bank

Figure 3: Economic indicators in agriculture of post-Soviet republics. 
and at the same time show a low share of rural population and workers in agriculture. The last group of countries is characterized by high proportions of rural population.

\section{Agricultural index}

Based on these four basic indicators for the status of agriculture within the national economy, the agriculture index was created.

$$
\begin{aligned}
A I & =1 / 4 A G R G D P+1 / 4 A G R E M P L+1 / 4 A G R V A \\
& +1 / 4 R U R P
\end{aligned}
$$

Where:

AI - agriculture index,

AGRGDP - the share of agriculture on GDP,

AGREMPL - the share of employment in agriculture,
AGRVA - agriculture value added per worker and RURP - the share of rural population.

In the case of the monitored countries, the agricultural index reaches its highest values in Tajikistan or Uzbekistan. Conversely, the Russian Federation or Kazakhstan show the lowest values. It might be concluded that the higher the agricultural index, the lower the GDP level per capita (PPP) in the monitored countries. This also corresponds with the negative value of the correlation coefficient -0.813 . The correlation is significant at the 0.01 level. Due to the fact that the coefficient value is higher than 0.7 , the degree of interdependence is high.

As is also evident in the case of the postSoviet republics, the trend connected with the decreasing importance of agriculture in GDP can be seen. Based on the analysis, it can be concluded

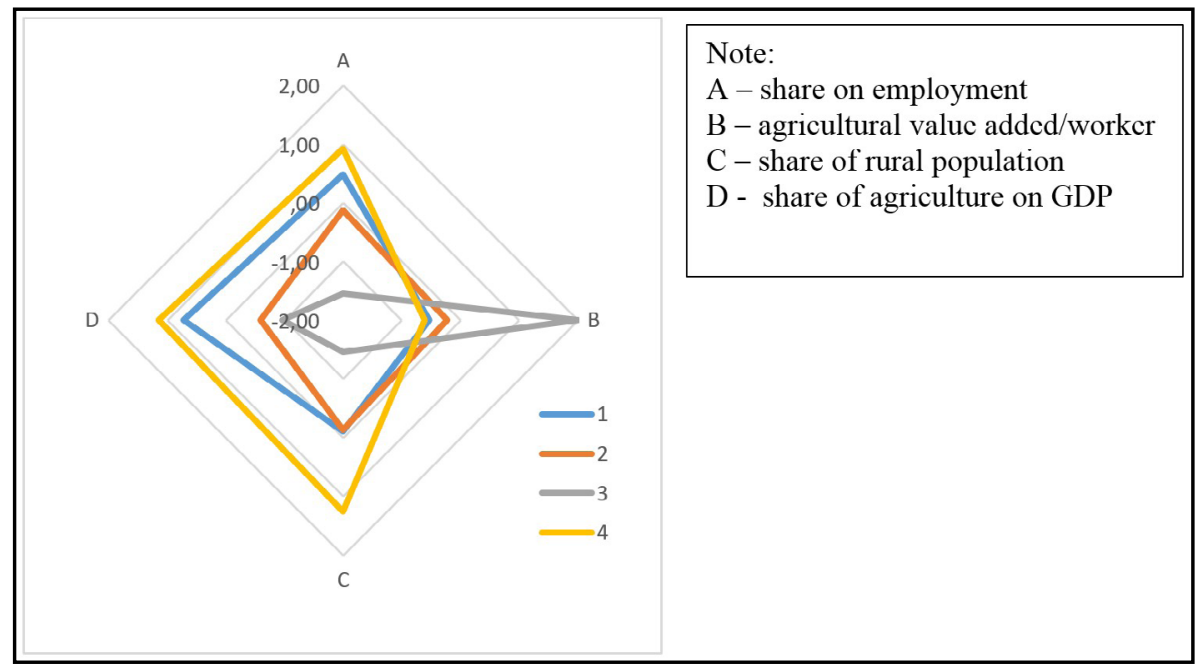

Source: own processing based on statistical data from WB, ILO, CIS and Eurasian Development Bank Figure 4: Average values of individual clusters.

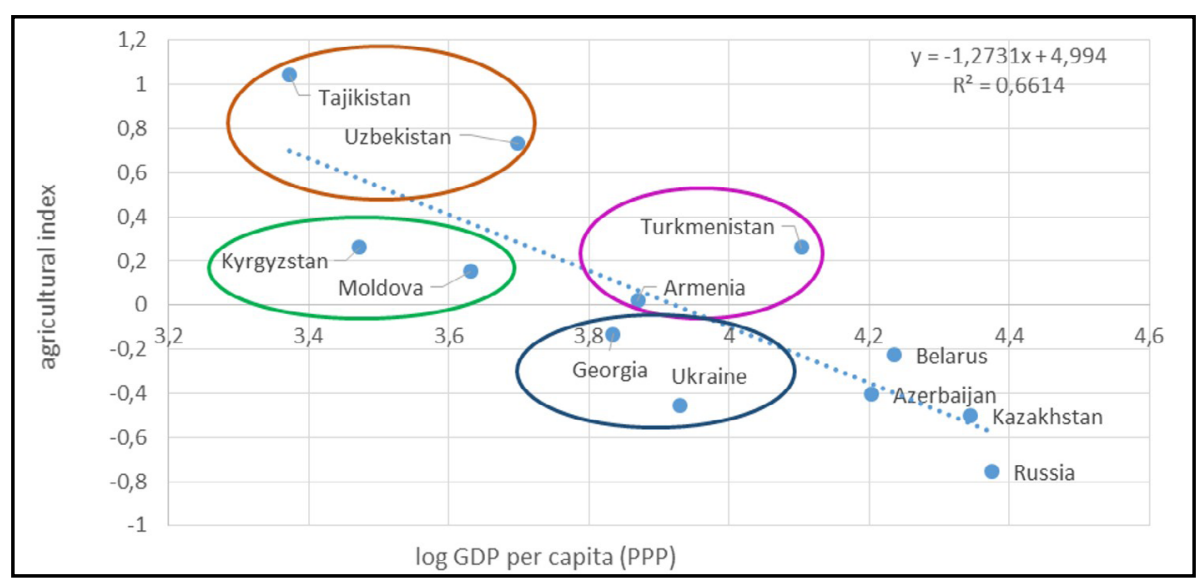

Source: own processing based on statistical data from WB, ILO, CIS and Eurasian Development Bank. Figure 5: Relation between agricultural index and log GDP per capita (PPP). 
that there are sub-clusters within agriculture of the post-Soviet countries, which follow a similar tendency. Out of all the monitored countries, Tajikistan or Uzbekistan are most dependent on agricultural production and their GDP per capita has long-term been low. On the contrary, Russia or Belarus are countries with lower contribution of agriculture to GDP (Ishchukova and Smutka 2013) and higher GDP per capita. At the same time, they are countries which have managed to sustain their food security, and therefore increased their self-sufficiency (Maitah and Smutka 2016). Ukraine occupies a special position in this regard which has been experiencing political instability since the so called Orange revolution that also strongly influences the country's economic situation. In this regard, however, Lerman (2009) points out that agricultural development of these countries is strongly influenced by political factors.

Nevertheless, it might be stated that economic differences within each country are closely connected with the change in the structure of the economy, in which dependence on agrarian sector, while labour productivity is stagnating, hinders economic development. This has also been confirmed by Caselli and Coleman II (2001) and Awokuse and Xie (2015). On the other hand, the total increase in the productivity factor in agriculture has been $1.5 \%$ higher than in non-agricultural business (Christiaensen, Demery and Kuhl, 2010).

\section{Conclusion}

The position of agriculture has witnessed a significant decline between 2000-2008 and then on the ground of the economic crisis it has been growing since 2009. Agriculture of the post-Soviet republics is very diverse, and we can find countries with high labour productivity among them (Belarus) or countries with a considerable number of employees and with the low level of productivity. The share of rural population fluctuate between $20 \%$ in Ukraine and Belarus and $70 \%$ in Tajikistan. At average $20 \%$ of the overall population work in agriculture. The income gap between agriculture and other sectors of the economy exists in all countries. Majority of the countries also have trade deficit with agricultural products. Tajikistan has the highest contribution of agriculture on GDP (27\%) compare to Russia (4\%).

The countries can be divided into four basic groups which differ in individual economic characteristics of the agricultural sector. Based on the analysis, it might be concluded that there are significant differences between Eurasian countries and the so called sub-clubs are created as part of cooperation.

In the case of the post-Soviet republics, a statistically important negative relation between the agriculture index value (contribution of agriculture to GDP, the share of employment in agriculture, agriculture value added per worker and the share of rural population) and low GDP per capita (PPP) can be verified. At the same time, it might be stated that the countries with a high value of agriculture index reach low values of GDP per capita.

As it is evident from the previous chapters, the post-Soviet republics are rather heterogeneous when taking into account agricultural variables. This offers them great potential for future co-operation. However, some of these countries (Tajikistan, Uzbekistan) can still be considered as predominantly agricultural with high contribution of agriculture to GDP. In addition, they have not undergone economic transition. Belarus, Kazakhstan and Russia should be able to supply some of the other countries with agricultural products. Ukraine also shows great potential; however, its "military conflict" with the separatists and the dispute over Crimea with Russia is problematic and hinders progress.

\section{Acknowledgements}

This paper was supported by Grant Agency of the Faculty of Economics and Management, Czech University of Life Sciences Prague: Is there any possibility for functional co-operation of the post-soviet countries? [no. 20161014].

Corresponding author:

Ing. Irena Benešová, Ph.D.

Department of Economics, Faculty of Economics and Management

Czech University of Life Sciences, Kamycka 129, Prague 6-Suchdol, 165 21, Czech Republic

E-mail: benesova@pef.czu.cz 


\section{References}

[1] Anderson, K., G. Rausser, and J. Swinnen. 2014. "Agricultural Policy: A Global View", In Encyclopedia of Agriculture and Food Systems, pp. 179-94. Elsevier. ISBN 978-0-08-093139-5. DOI: 10.1016/B978-0-444-52512-3.00120-0.

[2] Awokuse, T. O. and Ruizhi, X. (2015) "Does Agriculture Really Matter for Economic Growth in Developing Countries?", Canadian Journal of Agricultural Economics/Revue Canadienne D'agroeconomie, Vol. 63, No. 1, pp. 77-99. E- ISSN 1744-7976. DOI:10.1111/cjag.12038.

[3] Barro, R. (2004) "Current Protectionism and the Benefits of Free Trade" Journal of Policy Modeling Vol. 26, No. 4, pp. 507-12. ISSN 0161-8938. DOI: 10.1016/j.jpolmod.2004.04.005.

[4] Barro, R. J. and Xavier I. S. M. (2003) "Economic Growth", Second ed. Cambridge MA: MIT Press, ISBN 0-262-02553-1.

[5] Carter, M. (2004) "Landownership Inequality and the Income Distribution Consequences of Economic Growth", In Inequality Growth and Poverty in an Era of Liberalization and Globalization, pp. 57-80. Oxford University Press. ISBN 0-19-928410-5.

[6] Caselli, F. and Wilbur, J. C. II (2001) "The U.S. Structural Transformation and Regional Convergence: A Reinterpretation”, Journal of Political Economy, Vol. 109, No. 3, pp. 584-616. DOI: $10.1086 / 321015$, ISSN 0022-3808.

[7] Dutta, M. (2002) "Asian Economic Community: Intra-Community Macro-and-Micro-Economic Parameters", Journal of Asian Economics, Vol. 13, No.4, pp 447-91. ISSN 1049-0078. DOI: 10.1016/S1049-0078(02)00163-X.

[8] Eurasian Development Bank (2016) [Online] Available:http://eabr.org/r/[Accessed: 8 January 2016].

[9] FAOSTAT (2016) [Online] Available: http://faostat3.fao.org/home/E [Accessed: 8 January 2016].

[10] Fathipour, G. and Ghahremanlou, A. (2014) "Economical-Regional Integration - An Overview on Iran-India Trade Relation”, Procedia - Social and Behavioral Sciences, Vol. 157, pp. 155-164, ISSN 1877-0428. DOI:10.1016/j.sbspro.2014.11.019.

[11] Garmann, S. (2014) "Does Globalization Influence Protectionism? Empirical Evidence from Agricultural Support", Food Policy, Vol. 49, pp. 281-293. DOI: 10.1016/j.foodpol.2014.09.004.

[12] Hansen, H. O. (2016) "Agricultural Policy Schemes: Price and Support Systems in Agricultural Policy", In Reference Module in Food Science. ISSN 0306-9192. DOI: 10.1016/B978-0-08-1005965.01020-9.

[13] Higgins, B. (1956) “The 'Dualistic Theory' of Underdeveloped Areas", Economic Development and Cultural Change, Vol. 4, No. 4, pp. 99-115. ISSN 0013-0079.

[14] Hur, J., H., Alba, J. D. and Park, D. (2010) "Effects of Hub-and-Spoke Free Trade Agreements on Trade: A Panel Data Analysis" World Development, Vol. 38, pp. 1105-1113. ISSN 0305-750X. DOI:10.1016/j.worlddev.2010.02.009.

[15] Chenery, H. B. and Bruno, M. (1962) "Development Alternatives in an Open Economy: The Case of Israel", The Economic Journal, Vol. 72, No. 285, pp 79 - 86. E- ISSN 1468-0297. DOI: $10.2307 / 2228618$.

[16] Chong, S. Y., and Hur, J. (2008) "Small Hubs, Large Spokes and Overlapping Free Trade Agreements", World Economy, Vol. 31, No.12, pp. 1625-1665. ISSN 0305-750X. DOI:10.1111/j.1467-9701.2008.01118.x.

[17] Christiaensen, L. Demery, L. and Kuhl, J. (2010) “WIDER Working Paper No. 2010/36 The (Evolving) Role of Agriculture in Poverty Reduction." ISSN 1798-7237.

[18] International Labour Organization (ILO) (2016) [Online] Available: http://www.ilo.org/global/ statistics-and-databases/lang--en/index.htm [Accessed: 13 April 2016]. 
[19] Interstate Statistical Committeee of the Commonwealth of Independent States (2016) [Online] Available: http://www.cisstat.com/index.html [Accessed: 15 April 2016].

[20] Ishchukova, N. and Smutka, L. (2013) "Revealed Comparative Advantage of Russian Agricultural Export”, Acta Univeristatis Agriculturae et Silviculturae Mendelianae Brunensis, Vol. LXI 104, No. 4. ISSN 1211-8516. DOI: 10.11118/actaun201361040941.

[21] Jain, A. K. (2010) "Data Clustering: 50 Years beyond K-Means", Pattern Recognition Letters, Vol. 31, No. 8, pp. 651-66. ISSN 0167-8655. DOI:10.1016/j.patrec.2009.09.011.

[22] King, A., Ramlogan-Dobson, C. (2016a) "Is There Club Convergence in Latin America?", Empir Econ. ISSN 1435-8921. DOI:10.1007/s00181-015-1040-x.

[23] King, A., Ramlogan-Dobson, C. (2016b) "Regional Clubs in Agriculture: Empirical Evidence", Empir Econ, Vol. 8, pp. 512-15. ISSN 1435-8921. DOI:10.1016/j.protcy.2013.11.069.

[24] Kirkow, P. (1999) "Foreign Trade Arrangements in Russia and Its Regions: Relying on Foreign Capital to Generate Growth?", Post-Communist Economies, Vol. 11, No.1, pp. 79-98. ISSN 1465-3958. DOI:10.1080/14631379996057.

[25] Kodinariya, T. M, and Makwana, P. R. (2013) "Review on Determining Number of Cluster in K-Means Clustering", International Journal of Advance Research in Computer Science and Management Studies, Vol. 1, No. 6. ISSN 2321 - 7782.

[26] Kumar, S. (2015) "Regional Integration, Capital Mobility and Financial Intermediation Revisited: Application of General to Specific Method in Panel Data", Journal of International Financial Markets, Institutions and Money, Vol. 36, pp. 1-17. ISSN 1042-4431. DOI: 10.1016/j.intfin.2015.02.008.

[27] Lerman, Z. (2009) "Land Reform, Farm Structure, and Agricultural Performance in CIS Countries" China Economic Review, Vol. 20, pp. 316-26. DOI 10.1016/j.chieco.2008.10.007.

[28] Lewis, W. A. (1955) "The Theory of Economic Growth". London: Alleni \& Unwin. ISBN 0043300545.

[29] Lewis, W. A. (1954) "Economic Development with Unlimited Supplies of Labour." The Manchester School Blackwell Publishing Ltd, Vol. 22, No. 2, pp. 139-191. E- ISSN 1467-9957. DOI: 10.1111/j.1467-9957.1954.tb00021.x.

[30] Lewis, W. A. (1979) “The Dual Economy Revisited", The Manchester School Blackwell Publishing Ltd, Vol. 47, No. 3, pp. 211-229. E-ISSN 1467-9957. DOI: 10.1111/j.1467-9957.1979.tb00625.x.

[31] Libman, A. and Vinokurov. E. (2012) "Regional Integration and Economic Convergence in the PostSoviet Space: Experience of the Decade of Growth", Journal of Common Market Studies, Vol. 50, No. 1, pp. 112-128. E- ISSN 1468-5965. DOI: 10.1111/j.1468-5965.2011.02209.x.

[32] Maitah, M. and Smutka, L. (2016) "Restoration and Growth of the Russian Sugar Market", Sugar Tech, Vol. 18, No. 2, pp. 115-23. ISSN 0974-0740. DOI: 10.1007/s12355-015-0383-0.

[33] Mellor, B. F., Johnston; J. W. (1961) "The Role of Agriculture in Economic Development", The American Economic Review, Vol. 57, No. 3, pp. 415-426. ISSN 0002-8282.

[34] Meloun, M. and Militky, J. (2004) "Statisticka Analyza Experimentalnich Dat". 2. ed. Prague: Academia.

[35] Mostafa, G. (2013) “The Concept of 'Eurasia': Kazakhstan's Eurasian Policy and Itsimplications", Journal of Eurasian Studies, Vol. 4, No. 2, pp. 160-70. ISSN 1879-3665. DOI: 10.1016/j.euras.2013.03.006.

[36] Myint, H. (1971) "The Economics of the Developing Countries", $2^{\text {nd }}$ ed. London: Hutchinson University Library. 
[37] Obydenkova, A. (2011) "Comparative Regionalism: Eurasian Cooperation and European Integration. The Case for Neofunctionalism?” Journal of Eurasian Studies, Vol. 2, No. 2, pp. 87-102. ISSN 1879-3665. DOI: 10.1016/j.euras.2011.03.001.

[38] OECD (2008) "Handbook on Constructing Composite Indicators Methodology and User Guide." [Online] Available: http://www.oecd.org/els/soc/ handbookonconstructingcompositeindicatorsmethodologyanduserguide.htm [Accessed: 15 January 2016].

[39] Robertson, P. (1999) "Economic Growth and the Return to Capital in Developing Economies." Oxford Economic Papers, Vol. 51, No. 4, pp. 577-94. E-ISSN 1464-3812. DOI: 10.1093/oep/51.4.577.

[40] Robertson, P. E. and Landon-Lane, J. S. (2001) "Post War Industrialisation And Growth: What Can A Lewis Type Model Explain?", SSRN Electronic Journal, Vol. 53, pp. 210-211. DOI: $10.2139 / \mathrm{ssrn} .257946$.

[41] Rosentein-Rodan, P. N. (1943) "Problems of Industrialization of Eastern and South-Eastern Europe." The Economic Journal, E-ISSN 1468-0297.

[42] Saisana, M. and Saltelli. A. (2011) "Rankings and Ratings: Instructions for Use", Hague Journal on the Rule of Law, Vol. 3, No. 2, pp. 247-268. ISSN 1876-4045. DOI: 10.1017/S1876404511200058.

[43] Sharpe, A. and Brendon A. (2012) “An Assessment of Weighting Methodologies for Composite Indicators: The Case of the Index of Economic Well-Being." Ottawa. [Online] Available: http:// www.csls.ca/reports/csls2012-10.pdf. [Accessed: 20 January 2016].

[44] Svatoš, M., Smutka, L. and Ishchukova, N. (2014) "The Position of Agriculture in the Russian Federation", Agricultural Economics - Zemedelska Ekonomika, Vol. 60, No. 11, pp. 489-502. [Online] Available: http://www.agriculturejournals.cz/publicFiles/137997.pdf [Accessed: 5 March 2016]. ISSN 1805-9295

[45] Vinokurov, E. and Libman, A. (2012) "Eurasian Integration: Challenges of Transcontinental Regionalism”, Basingtoke: Palgrave Macmillan. ISBN 978-230-30266-6.

[46] Wagstaff, K., Cardie,C., Rogers, S. and Schroedl, S. (2001) "Constrained K-Means Clustering with Background Knowledge”, International Conference on Machine Learning, pp. 577-584.

[47] Ward, J. H. Jr. (1963) "Hierarchical Grouping to Optimize and Objective Function", Journal of the American Statistical Association, Vol. 58, No. 301, March 1963, pp. 236-244. [Online] Available: http://iv.slis.indiana.edu/sw/data/ward.pdf. [Accessed: 10 February 2016]. ISSN $1537-274 X$.

[48] Wegren, S. K. (2016) "Food Policy in Russia." In Reference Module in Food Science. ISBN 978-0-08-100596-5. DOI: 10.1016/B978-0-08-100596-5.03331-X.

[49] World Bank (WB) (2016) World Development Indikators (WDI) [Online] Available: http://datacatalog.worldbank.org/[Accessed: 22 February 2016]. 


\section{APPENDIX 1 Variables entering the analysis}

Agricultural Products, Total (share on total merchandise trade (\%)

Agricultural land (\% of land area)

Agriculture (PIN/worker in agriculture)

Agriculture value added per worker (constant 2005 US\$)

Agriculture, value added (\% of GDP)

Arable land (\% of agricultural land area)

Arable land (\% of land area)

Average alleviation above the level

Barley Yield ( $\mathrm{Hg} / \mathrm{Ha})$

Beef and Buffalo Meat

Beverages Tobacco (share on total agricultural trade (\%)

Cereals, Total

Cereals, Total (PIN/worker in agriculture

Crops (PIN/worker in agriculture

Crude Materials -Ex2 (share on total agricultural trade (\%)

Dairy Products Eggs (share on total agricultural trade (\%)

Eggs Primary

Employment in agriculture (\% of total employment)

Employment in agriculture (\% of total population)

Food (PIN/worker in agriculture

Food and Animals (share on total agricultural trade (\%)

Food and Animals (share on total agricultural trade (\%)

Forest area ( $\%$ of land area)

Fruit + Vegetables (share on total agricultural trade (\%)

Industry, value added (\% of GDP)

Land under cereal production (\% of arable land)

Livestock (PIN/worker in agriculture

Maize Yield ( $\mathrm{Hg} / \mathrm{Ha})$

Meat and Meat Preparations (share on total agricultural trade (\%)

Meat indigenous, cattle and buffalo

Meat, Poultry

Milk, Total

Nitrogen + Phosphate Fertilizers (N+P205 total nutrients)

Nitrogen Fertilizers ( $\mathrm{N}$ total nutrients)

Non Food (PIN/worker in agriculture)

Oats Yield $(\mathrm{Hg} / \mathrm{Ha})$ 
Permanent cropland (\% of land area)

Permanent crops \% of Agricultural Area

Permanent meadows and pastures \% of Agricultural Area

Phosphate Fertilizers (P205 total nutrients)/ha

Rural population (\% of total population)

Services, etc., value added (\% of GDP)

Sheep and Goat Meat kg/per capita/year

Total area equipped for irrigation \% of Agricultural Area

Wheat Yield $(\mathrm{Hg} / \mathrm{Ha})$ 